NBSIR 78-1476

\begin{tabular}{l} 
Precision Laboratory Standards \\
of Mass and Laboratory Weights \\
\hline
\end{tabular}

A reprint of NBS Circular 547, Section 1

by Lashof and Macurdy, Aug. 1954

October 1978

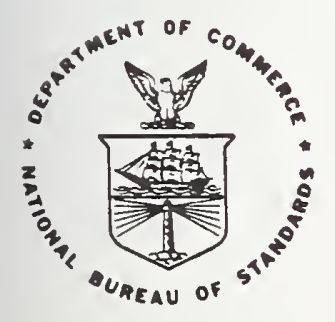

U.S. DEPARTMENT OF COMMERCE

NATIONAL BUREAU OF STANDARDS 


\section{PRE FACE}

National Bureau of Standards, Circular 547, Section 1, "Precision Laboratory Standards of Mass and Laboratory Weights," served for many years as a defining authority for various classes of weights and associated adjustment tolerences. Technological and organizational changes which occurred within a few years after the issuance gradually led to its obsolescence and consequently, it has been out of print for some t1me. In the interim, a new standard ASTM E617-78, "Lab Weights Precision Mass Standards, " has been issued updating the same subject matter. There are still numerous requests for Circular 547 since it is widely referenced in the literature. While the document is reprinted in its entirety in NBS Handbook 77, this source is also out of print and available only at certain repository libraries. Because of technical content and historical value of Circular 547, it is being issued in the NBSIR series* of documents, to be available through NTIS. It should be noted, however, that for matters concerning calibration, one should refer to the latest copy of NBS SP-250, "Calibration and Test Services of the National Bureau of Standards", available from the Office of Measurement Services.

SSections 5, 6, and 7 , which refer to obsolete procedures, have been deleted. 
NBSIR 78-1476

\section{PRECISION LABORATORY STANDARDS OF MASS AND LABORATORY WEIGHTS}

A reprint of NBS Circular 547. Section 1

by Lashof and Macurdy, Aug. 1954

October 1978

U.S. DEPARTMENT OF COMMERCE, Juanita M. Kreps, Secretary

Dr. Sidney Harman, Under Secretary

Jordan J. Baruch, Assistant Secretary for Science and Technology

NATIONAL BUREAU OF STANDARDS, Ernest Ambler, Director 
. 
National Bureau of Standards Circular 3, Design and Test of Standards of Mass, has been a basic reference on mass standards and weighing since its publication in 1918. The expanding needs of science, industry, and commerce call for the replacement of Circular 3 by a larger and more comprehensive document. Because of the time required to prepare a single large document, it is planned instead to prepare a series of publications covering the subject matter of Circular 3 and issue each as it is completed.

This first publication presents the specifications of the National Bureau of Standards for precision laboratory standards and other laboratory weights. It also presents the regulations governing the submission of these weights to the Bureau for test, and outlines the weight-calibration service of the Bureau. It supersedes chapters VI, VII, and XI and related portions of other chapters of Circular 3.

Other publications will present specifications for commercial standards of mass, methods of weighing, tests for sets of weights, a discussion of fundamental standards and concepts, and the design and test of balances and scales.

The material presented here is based not only on the third (1918) edition of Circular 3, prepared by A.T. Pienkowsky, but also on Mr. Pienkowsky's 1941 manuscript for a fourth edition. It also is based on suggestions and assistance received from manufacturers and suppliers of weights for scientific use at the 1952 Annual Meeting of the Scientific Apparatus Makers Association.

A.V. Astin, Director

1954

ERRATA TO CIRCULAR 547 SECTION 1, PRECISION LABORATORY STANDARDS OF MASS AND LABORATORY WEIGHTS

Page 10, Table 7, Acceptance tolerances ${ }^{1}$ for class $M$ weights is revised as follows:

1. The acceptance tolerance applies to both Class $\mathrm{M}$ and Class $\mathrm{J}$ weights.

2. The individual tolerances below 1 gram is changed to $0.010 \mathrm{mg}$.

3. The group tolerance for each group of weights in a particular decade below 1 gram is changed to $0.020 \mathrm{mg}$.

${ }^{1}$ All paragraphs referring to this table shall be revised to reflect these changes, in particular, the tolerance of $0.003 \mathrm{mg}$ for Class $\mathrm{J}$ weights has been changed to $0.010 \mathrm{mg}$.

April 10, 1962 



\section{CONTENTS}

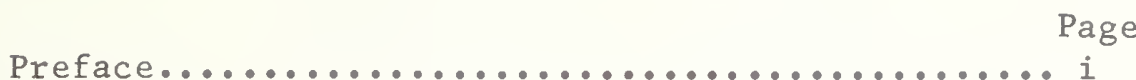

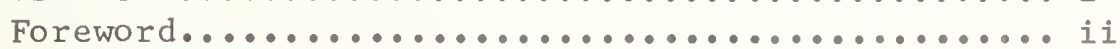

1. Introduction............................ 1

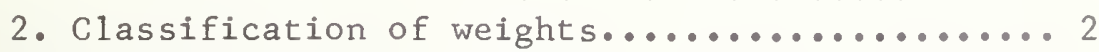

3. Requirements for precision laboratory standards of mass -- Classes $J, M, s$, and $S-1 \ldots . . . . . .3$

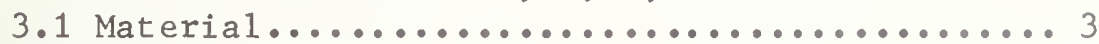

3.2 Design............................... 4

3.3 Surface................................ 4

3.4 Denominations........................... 4

3.5 Marking of weights..................... 6

3.6 Lifters.............................. 7

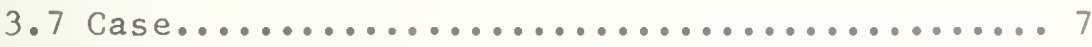

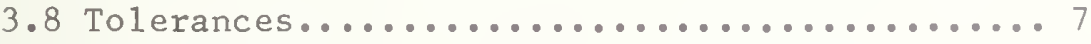

3.9 Constancy under variations in humidity....... 11

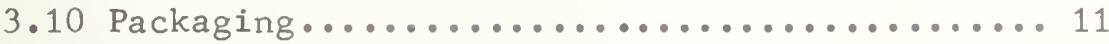

4. Requirements for laboratory weights

Classes $\mathrm{P}, \mathrm{Q}$, and $\mathrm{T} \ldots \ldots . . . . . .12$

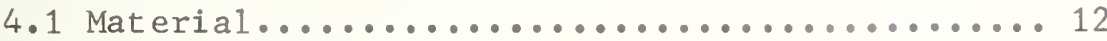

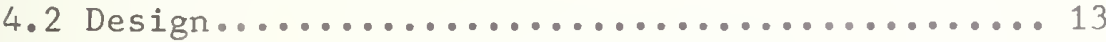

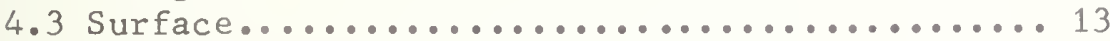

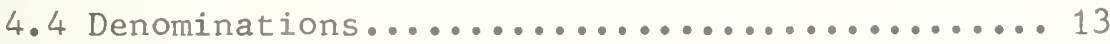

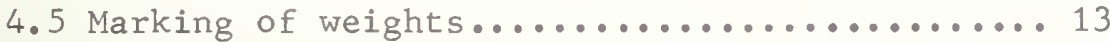

4.6 Lifters............................... 14

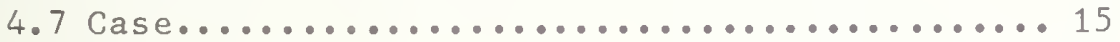

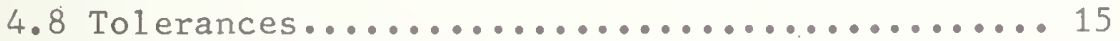

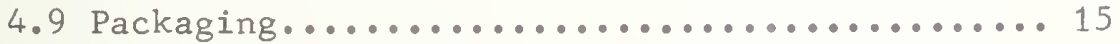

Appendix 1. Conversion factors for

units of mass........... 20

Appendix 2. Units and abbreviations for

marking weights........... 21 
. 


\title{
Precision Laboratory Standards of Mass and Laboratory Weights
}

\author{
T. W. Lashof and L. B. Macurdy
}

\begin{abstract}
This is the first part of the revision of National Bureau of Standards Circular 3, Design and Test of Standards of Mass, last revised in 1918. Laboratory standards of mass in order of decreasing precision are classes $\mathrm{J}, \mathrm{M}, \mathrm{S}$, and $\mathrm{S}-1$. The newly introduced class $\mathrm{J}$ weights, with a tolerance of 0.003 milligram for each weight, may be used for the calibration of equipment for ultramicroanalysis. Class $M$ weights are reference standards for highprecision work and work demanding high constancy. Class $\mathrm{S}$ weights arn laboratory working standards. Maintenance tolerances start at 0.0054 milligram fol class M fractional weights and 0.014 milligram for the smallest class $S$ weights, and decrease to 5 parts per million for the larger weights of both classes. Cliss S-1 are for use in rontine analytical work with quick-weighing balances and are the nust precise weights available in nomnetric units. Tolerances vary from 0.025 milligram for the smallest weights to 10 parts per milliun
for the larger weights.

Classifed for the first time are class $P$ laboratory weights for routine analytical work, class $Q$ for technical and student use, and class $T$ for rough weighing operations. Muintenance tolerances for these weights start at 0.1 milligram for classes $P^{\prime}$ and $Q$ and 0.8 unilliyram for class $T$ and decrease to 40,100 , and 300 parts per million, respectively, for the larger weights of these classes.

In addition to the tolerances, the denominations, composition, construction, marking, packing, and performance of weights of each class are fully described. Also described are the nature and precision of the tests available and other features of the 13ureau's Weight calibration service. In general, the calibration service is intended primarily to provite. standard weights for the calibration of other weights, for legal use, and for use in scientific work where the highest precision is required.
\end{abstract}

\section{Introduction}

The National Bureau of Standards throughout its history has been the center in the United States for the calibration of precision standards of mass. Because of its position, which stems from its custody of the national standards of mass, the Bureau has been the logical source of a system of classification for both commercial and scientific weights. Although the National Bureau of Standards is not invested with the authority to impose mandatory classifications and tolerances for wcights, the classifications and tolerances that have been recommended by the Bureau have met with almost universal acceptance in this country.

'The first classification issued by the National Bureuu of Standards was given in Circular 3, in 1903. This was revised in 1907 and again in 1918. The 1918 revision of the Circular (although out of print for 25 years or more) has continued us a basic reference on mass standards up to the present time, even though additional classes of weights have been added to supplement the original ones.

During the 35 years that have passed since the publication of the third edition of Circular 3 , a great expansion of scientific, technical, and commercial activity has taken place, bringing with it the need for new classes of weights and demands for improved constancy and accuracy in certain ranges of the established classes of weights. The major changes that have been made to mect these needs are:

1. The introduction of a new class $J$ for rery accurately adjusted microweights.

2. The use of tighter tolerances for classes M and $\mathrm{S}$, especially for the smaller weirhts, in order that in semimicro and analytical work the corrections for these weights nolmully miay be neglected.

3. The introduction of "group" tolerances in classes $\mathrm{M}$ and $\mathrm{S}$, for the above purpose, alld in order to prevent accuniulation of errors when many small weights are used.

4. The separation of class $\mathrm{S}$ into an improved class $\mathrm{S}$ and a new class $\mathrm{S}-1$, the latter being almost the equivalent of the class $S$ of Circular 3 , third edition, and these two classes conforming to the trade practice of double- and single-chectied weights.

5. The provision of nonmetric lenominations under class S-1, to meet the need for laboratory standards in these denominations.

6 . The introduction of three classe't, $P, Q$, and $\mathrm{T}$, of rough laboratory weights, essentially equivalent to the classes of weights now available from the laboratory supply houses, in order to provide the standardization desired by the industry.

7. The use of a double tolerance scheme (acceptance tolerances for new or newly adjusted 
weights and maintenance tolerances for weights that have been in us('), which recognizes that weights of certain denominations and classes can and should be adjusted very closely so that they will remain within useful tolerances for a reasonable length of time.

8. A more detailed statement of the requirements, particularly with regard to material, design, and surface finish, and other factors that affect the constancy of weights, with a tightening of these requirements for classes $M$ and $S$.

Several manufacturers are now making weights that meet the closer tolerances and other requirements for classes $M$ and $S$ mèntioned above. As a matter of fact, the Bureau in 1951 increased the accuracy and precision with which it certified these weights. Modern research and the new quick-weighing devices demand the improved constancy and accuracy.

The Bureau will accept weights for certification under these new requirements, beginning 3 months after the date of this publication. For a period of a year after the date of this publication, the
Bureau will continue to ortify wights under the previous requirements of ('irrular :3. $\quad$ ftre 1 he end of the 1-year period, noncommereial weights will be tested on the basis of these new requirements, and will be certified under one of the classes J, M, S, S-1, P, Q, and T, only when tliey meet all the requirements contained herein for the class for whicl they are submittel.

Although every effort has been made to meet present needs and to anticipate future needs for scientific mass standards and other laboratory weights, situations undoubtedly will arise that will indicate the need for amendments and additions to the material contained in this publication. The staff of the National Bureau of Standards will consider suggestions for modifications of these specifications. Recommendations for changes should be submitted to the National Bureau of Standards in writing, with sufficient detail and with the information, research documents, ete., necessary to establisl the need for the recommended changes.

\section{Classification of Weights}

Weights may be divided into four groups according to their use, namely, precision laboratory standards, laboratory weights, commercial standards, and trade weights. Precision laboratory standards include weights used in scientific and technical laboratories as standards of mass for the calibration of other weights and weighing equipment or as precision laboratory weights for analytical work. Laboratory weights include weights used for rough analytical work and for general laboratory and technical work. Commercial standards include the State, office, and working standards used in law enforcement. Trade weights include weights used in the purchase and sale of goods both by the Government and in orlinary trade.

Table 1 lists the classes of weights under each of these groups except the trade group. The classification, specifications, and regulations for trade weights (as adopted by the National Conference of Weights and Measures and recommended by the National Bureau of Standards for promulgation by the several States) are covered in NBS Handbook 44, revised to date, or its successor.

The intended use or purpose of weights of each of the laboratory classes is given at the beginning of chapters 3 and 4 ; that for each of the commercial classes $(A, B$, and $C)$ is given in Circular $3 .^{2}$

\footnotetext{
1 NBS Handbook 44, Speclfacations, tolerances, and regulations for commcrcial welghts and mensures, and beighing and measuring devices, for sale by the Superintendent of Documents, U. S. Oovernment Printing Oflice, Wushington 25, D. C..\$1.25

NBS Circular 3, 3d ed, Desirn and test of standards of mass (1918.) Out of print, but available in many lifbraries.
}

TABLE 1. National Bureau of Standards classification of weights

\begin{tabular}{|c|c|}
\hline Class & Application \\
\hline \multicolumn{2}{|r|}{ Precision Laboratory STANDaRds } \\
\hline $\mathrm{J}$ & Microweight standards (microbalance work). \\
\hline$M$ & $\begin{array}{l}\text { High-precision scientific standards (reference, } \\
\text { high-precision, and high-constancy worh). }\end{array}$ \\
\hline $\mathrm{S}$ & $\begin{array}{l}\text { Scientific standards (reference, ('alibration, and } \\
\text { precision analytical work). }\end{array}$ \\
\hline S-1 & $\begin{array}{l}\text { Laboratory standards (routine analytical and } \\
\text { precision nomnetric work). }\end{array}$ \\
\hline
\end{tabular}

LABORATORY WEIGHTS

P 1 Analytical and precise tcchnical weights

Q Geileral laboratory, techuical, and student weights.

T Utility weights.

Commercial Standards (reference, working, and field standards used in law enforccucut)
A 3 State primary standards.
$\mathrm{B}^{2} \quad$ State working standards.
$\mathrm{C}^{2}$ Test weights.

Trade Weights (weights used in the sale of comınodities and services)

See classes listed in NBS Handbook 44.

I Formerly class $3-2$.

This classifacation is briog revised 


\section{Requirements for Precision Laboratory Standards of Mass- Classes J, M, S, and S-1}

Class J. These are metric weights designed primarily as standards for the calibration of weighing equipment used in the precise determination of very small masses in ultramicroanalysis. The effect of changes in relative humidity will be small for properly constructed class $J$ weights.

Class $M$. These are metric weights designed for use as reference standards, for work of the highest precision, and for investigations demanding a high degree of constancy over a period of time. Tolerances for class $M$ weights up to $5 \mathrm{~g}$ have been so selected that for most semimicro and microchemical work the corrections for the individual weights may be neglected.

When used with care, properly constructed class $M$ weights will be constant within considerably less than the prescribed tolerances. As a group, these weights sliould be constant for several years within the indicated accuracy of the highprecision class MI calibration (see 5.1, class M (a)).

Class $S$. 'These are metric weights designed as working standards for the calibration of other weights or as high-precision analytical weights for the more precise weighings in physical and chemical laboratories and in assay work. The tolerances for class $\mathrm{S}$ weights are such that the weights may be used without corrections, other than allowance for air buoyancy, for most analytical work and as keyboard or dial-controlled weights in quick-weighing analytical balances having a $200-\mathrm{g}$ capacity.

Class S weights may be used also as reference standards. However, they may not be expected to remain as constant as class $M$ weights.

Class $S-1$. These are designed for use as precision laboratory weights in routine analytical work with balances using quick-weighing devices, such as a chain. Class S-1 weights bridge the area between the best laboratory weights (class P) and the precision laboratory standards. Class S-1 includes weights in avoirdupois, apothecary, troy, and certain other units (see table 4), as well as those in metric units. Weights that meet class $S-1$ specifications are the most precise laboratory working standards currently available in nonmetric units.

\subsection{Material}

\subsubsection{HARDNESS}

C'lass J. Weights shall be constructed of hard, nonporous material, resistant to abrasion, and not likely to chip or spall in use. The Knoop hardness number of this material when determined at a test load of $100 \mathrm{~g}$ shall be 165 or greater (e. g., platinum-iridium or tantalum).

C'lasses $M, S$, and $S-1$. The hardness requirement shall apply to the material of which the body (including knob) of the weight is constructed and also to the plating of a plated weight, except as noted below under 3.1.1.1. The Knoop hardness number shall be as follows: (a) 125 or greater at a test load of $200 \mathrm{~g}$ for weights above $30 \mathrm{mg}$ or equivalent (brass and harder materials, such as stainless steel); (b) $55 \mathrm{ol}^{\circ}$ greater at a test load of $100 \mathrm{~g}$ for weights $30 \mathrm{mg}$ and below (aluminum and harder materials).

\subsubsection{Option}

Classes $M$ and $S$. At the option of the purchaser, if class $\mathrm{M}$ or $\mathrm{S}$ weights are to be used as reference standards, the surface of weights $1 \mathrm{~g}$ and above may be protected with gold.

\subsubsection{Corrosion Resistance}

Classes $J, M, S$, and $S-1$. Weights shall be constructed of naterial that is resistant to oxidation or corrosion, except as follows:

Classes $M, S$, and $S-1$. Brass and materials similarly susceptible to oxidation and corrosion may be used for weights $1 \mathrm{~g}$ and above, provided that the surface is suitably protected in accordance with 3.3.3. Aluninum, aluminum alloys, and other metals that have resistance to oxidation and corrosion, depending largely on the surfuce condition of the metal, may be used only when the surface will take and hold a high polish.

\subsubsection{Adjusting Material}

Classes $S$ and $S-1$. Tantalum, copper, aluminum, tin, or material equally resistant to oxidation and corrosion shall be used if adjusting material is required. Materials that readily oxidize and corrode (lead, dirt, powdered materials, crganic materials, such as paper and oil, etc.) shall not be used in adjusting cavities.

\subsubsection{Contamination}

Classes $J, M, S$, and $S-1$. All surfaces, exterior and interior (including the acljusting cavity and threads of the knob) shall be free of deposits, residues, and other contaminating substances, such as residues from electroplating and cleaning solutions.

\section{.3.1.3. Magnetic Properties}

Classes J, M, S, and $S-1$. Weights shall be constructed of nonmagnetic material. Nivther ferromagnetic nor strongly paramagnetic materials may be used.

Classes $S$ and $S-1$. Nonmagnetic stainless-steel alloys (including type 18-8) may be used, provided the nickel content is at least 50 percent by weight of the chromium content.

\subsubsection{Density}

Classes $J$ and $M$. No requirements.

Classes $S$ and $S-1$. The total volume, including any air-tight cavity, shall be such that the average density is within the ranges shown in table 2. 
TABLD 2. Density for class $S$ and $S-1$ weights

\begin{tabular}{|c|c|}
\hline Weights & Allowed denafty \\
\hline $\begin{array}{l}\text { Greater than } 1 \mathrm{~g} \text { (or equivalent) } \\
1 \mathrm{~g} \text { to } 50 \mathrm{mg} \text {, inclusive (or equiv- } \\
\text { alent) } \\
\text { Less than } 50 \mathrm{mg}\end{array}$ & $\begin{array}{l}7.8 \text { to } 9.1 \\
4.5 \text { and up } \\
2.6 \text { and up }\end{array}$ \\
\hline
\end{tabular}

\subsection{Design}

\subsubsection{General Shape}

Classes $J, M, S$, and $S-1$. A weight may have any shape that does not introduce features that reduce the reliability of the weight. All weights shall be free of ragged or sharp edges or ends. Wire weights shall not be excessively long and shall not be tightly coiled or otherwise shaped so as to have a tendency to catch and hold lint or dust. Both sheet-metal and wire weights shall be free from cracks sucl as may be formed in bending.

\subsubsection{ThiCKNESS}

Classes $J, M, S$, and $S-1$. Sheet-metal weights shall not be unnecessarily thin. In particular, the weights shall not be so thin that the surface tension of water will bend them out of shape.

Class $J$. The nominal thicknesses of the material from which sheet-metal weights are formed shall be equal to or greater than the values in table 3. The actual thickness shall be not less than 90 percent of the nominal thickness.

\subsubsection{Nomber of Pieces}

Classes $J, M, S$, and $S-1$. The entire weight shall be a single piece and homogeneous, except as follows:

Class M. Surfrce protection in accordance with 3.3.3; gold adjusting material fused on the upper surface of sheet-metal weights.

Classes $S$ and $S-1$. Surface protection (3.3.3); means of adjustment (such as a screw knob covering an adjusting cavity); adjusting material in adjusting cavity; gold adjusting material fused on the upper surface of sheet-metal weights.

'TABLE 3. Nominal thickness for class $J$ sheet-metal (Minimum values)

\begin{tabular}{|c|c|c|c|}
\hline Weight & Thickness & Weight & Thickness \\
\hline$m_{0}$ & in & mo & in. \\
50 & 0.0034 & 1 & 0.0009 \\
30 & $.00+4$ & 0.5 & .0006 \\
20 & .0042 & .3 & .00045 \\
10 & $.0(1): 31$ & .2 & .00037 \\
5 & .002 .3 & .1 & .00026 \\
3 & .0015 & .05 & .00019 \\
2 & .0013 & & \\
\hline
\end{tabular}

\subsection{Surface}

\subsubsection{IRREGUIAAITIIFS}

Classes $J$ and $M$. The entiro surfnce of the weight shall br smooth, except for such markinus as aro allowed under 3.5 , and shall be highly polished.

Classes $S$ and $S-1$. The entire surface of the weights shall be smooth, except for such markings as are required under 3.5 , and shall be carefully polished or have equivalent finish.

\subsubsection{Porosity}

Classes $J, M, S$, and $S-1$. When subjected to unaided visual inspection, the surface shall appear free from pits and pores and shall show no effects of porosity.

\subsubsection{Protection}

(a) Laraer Weights (i. e., weights other than sheet-metal or wire weights)

Class $M$. Weights of brass, bron\%c, or other metals that tarnish on exposure to the atmosphere shall be plated with platinum, rhodium, or other suitable metal. Gold plating may be used at option of purchaser (3.1.1.1). There shatl be no darkening of the surface and no formation of spots of any kind when the weights nie boiled for 3 half-hour periods in distilled water and cooled in distilled water between boilings, or when the weights are subsequently dricd at a temperature of $110^{\circ} \mathrm{C}$ for 1 hour.

Classes $S$ and $S-1$. Unless the surface material is at least as resistant to atmospheric corrosion as aluminum, it shall be plated with metals such as platinum or rhodium, or shall be lacquered. Lacquer, if used, shall be hard, oi only moderate thickness, transparent, and not easily chipped. Lacquer shall not be used, howevel, on weight: that are made of, or are plated with, il material that normally need not be protected atrainst oxidation or corrosion. Gold plating shall not he used as the final coating, except that class it wrights that are to be used as relerence standiards may be gold plated at option of purchaser (3.1.1.1).

\section{(b) SHeet-Metal and Wire Weights}

Classes $J, M, S$, and $S-1$. Sheet-metal and wire weights shall be made of a material that requires no surface protection. If these weights are achjusted by fusing or plisting, the adjustume matcrial shall require no surface protection. Lasequer or other coatings, other than electroplating, shall $110 \mathrm{t}$ be used.

\subsection{Denominations}

\subsubsection{System in Which Denominations Are Expressen. \\ Classes $J, M$, and $S$. The system shall be metric.}


Class $S-1$. The system shall be metric, avoirdupois, apothecary, troy, or certain other units as set forth in table 4.

3.4.2. Individual Weights.

Classes $J, M, S$, and $S-1$. The denominations shall be selected from table 4, except when weights are intended for a special application.

\subsubsection{SETS of W EIGHTS.}

Classes J, $M, S$, and $S-1$. The weights included in a set shall be sufficient for each weight of the set to be compared directly with another weight of the set or with a summation of other weights of the set.

\subsubsection{Optional Series.}

Classes $J, M, S$, and $S-1$. The weights of a set may be arranged in one or more of the following series: $5-2-1-1-1 ; \quad 5-2-2-1-1$; $5-3-2-1-1$; or 8-4-2-1-1; or equivalent as specified in 3.4.3. The unit in boldface represents a summation of smaller weights of the set. When there are no smaller weights in the set, the unit in boldface represents an additional weight that is required by 3.4 .3 in the 5-2-1-1-1 and $8-4-2-1-1$ series, but which may be omitted in the $5-2-2-1-1$ or 5-3-2-1-1 series.

Table 4. Preferred denominations for precision laboratory standards of mass

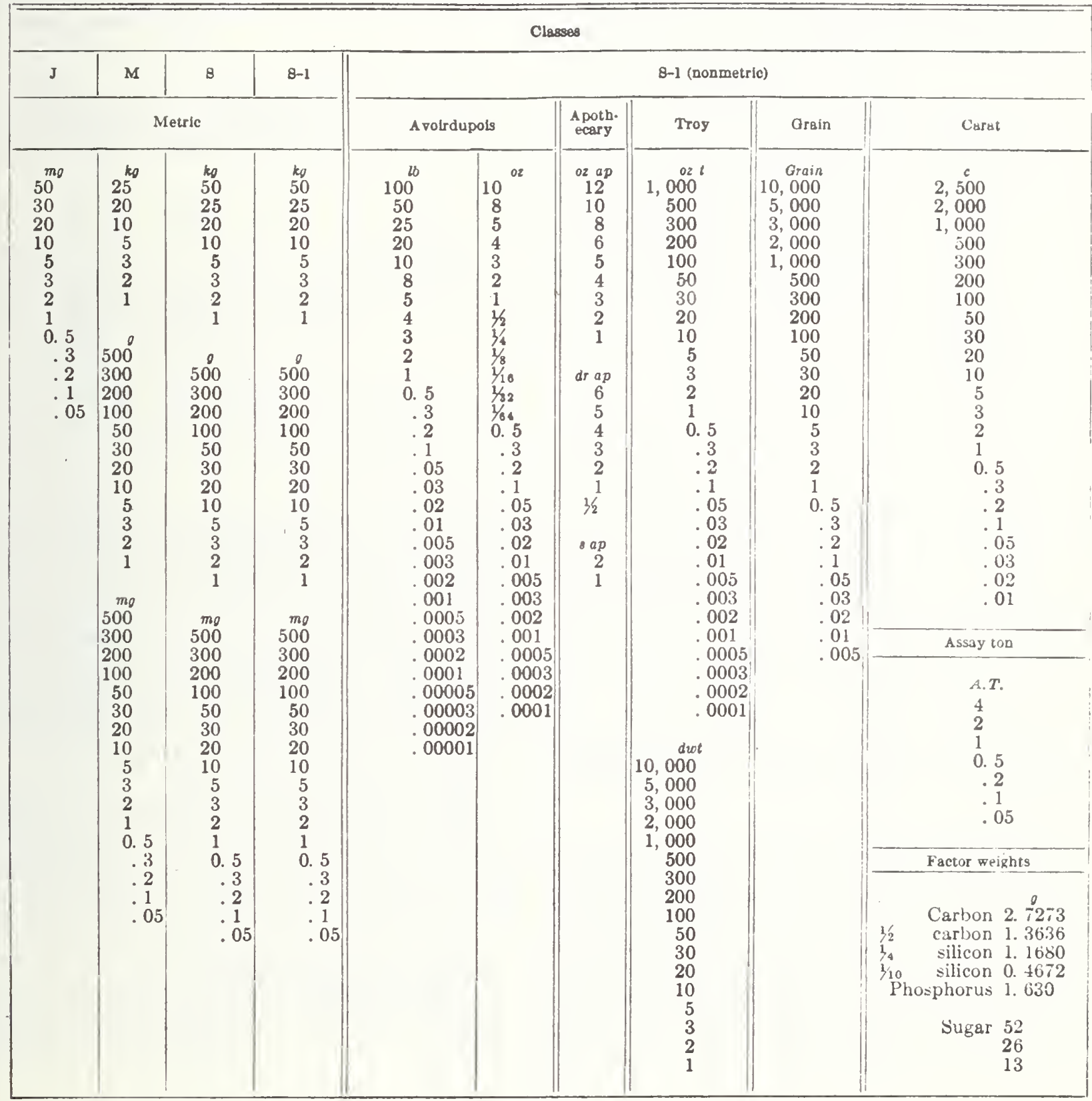


TABLE 5. Maximum and minimum denominations of commonly used sets of precision laboralory slandarls of mass

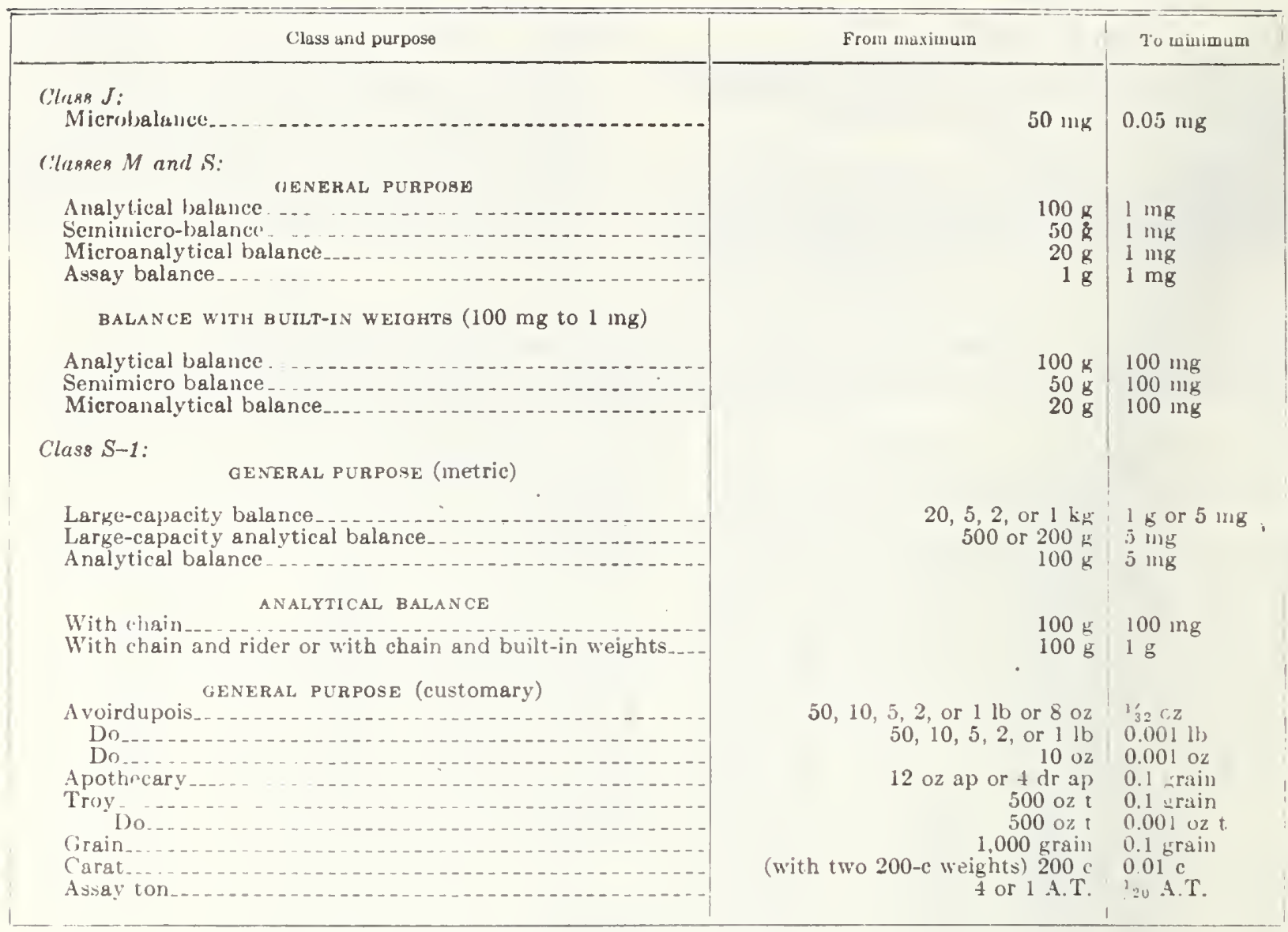

\subsubsection{Optroxal Maximum and Minmum De- NOMINATYONS.}

("lesses $J, M, S$, and $S-1$. Naximum and minimum denominations of commonly used sets of haboritory standards of mass are given in table 5

\subsection{Marking of Weights}

\subsubsection{Dexomination}

Classes $J, 1 /, S$, and $S-1$. Weiglits shall be marked with the number and unit, as specified in 3.5.1.1 and 3.5 .1 .2

\subsubsection{NinHzR}

By "mumber" is meant the number representing the nominal mass ol "value" of each weight as expressed in terms of some acceptable unit.

('la:s $\%$ If the sliape or size of a weight does no) distinguish it from oller wrights of the set, it may be marked with small shallow dots or other distinguishing matks. The numbers may be murkerl on the larger weights, and, if marked, shall be expressed in milligrams.
Class M. The numbers may be nuarked on the weights, and if markel, shall be expressed in kilograms, grams, ol milliyrans.

Class $S$. The number slull be plainly marked upon each weight, except in the easie of liders and other wire weights, and shall be expressed in kilograms, grams, or milligrams.

Class $S-1$. The number shall be plainly marked upon each weight, except in the case of rider's and other wire weights, and shall be cxpressed in terms of one of the units listed in appendix 2 .

\subsubsection{Unit}

Classes $J, M, S$, and $S-1$. The unit (in terms of which the nominal value of cach weight is c $x-$ pressed) shall be as specified in 3.5.1.1 for 'ach class. The name of the unit, if abbreviated, shall be abbreviated in accordance with appentix 2 . The abbreviation shall not include a perioul.

Classes $J$ and $M$. The unit shall not be nurked on weights less than $100 \mathrm{~g}$.

Classes $S$ and $S-1$ (metric). Thr unit may lw marked on the larger shcet-metal and cylindrical weights. 
('lass $S-1$ (nonmetric). The markings shall incude the nume of the unit or its aceepted abbreviation in aceordance with appendix 2 , exeept that on cylindrinal weights below-y/2 oz or equivalent and on sheet-metal woights below 1 grain or equivalent, the name of the unit may be omitted when spnce does not permit, its inclusion in legible form.

\subsubsection{Duplicate Weights}

r'lasses $J, M, S$, and $S-1$. Duplicate weights shall cacl be marked with one or more distinguishing marks.

\subsubsection{Unnecessary Markings}

Classes $J, M, S$, and $S-1$. Markings other than those required or allowed in 3.5.1.1, 3.5.1.2, and 3.5 .2 shall not be used.

\subsubsection{Depth of Markings}

Classes $J, M, S$, and $S-1$. Markings shall be shallow, relatively broad, and free from burrs aurl sharp angles. The markings shall not perforate or crack sheet-metal weights.

\subsection{Lifters}

Classes $J, M, S$, and $S-1$. Special lifters or forceps shall bo provided for sets of weights. Lifters or foreeps shall be provirled for individual weights when specified by the purchaser.

\subsubsection{DESIGN OF LifTERS}

('lasses $J, M, S$, and $S-1$. The lifters or forceps shall hold securcly the woights for which they are designed. Additional pressure shall not cause the dropping of small weights or the forceful ejection of lyrge weiglits.

(a) Fol weights $500 \mathrm{~g}$ and larger the parts of the lifters that may come into contact with the wrights shall be covered with some material softer than the surface of the weight, such as plastic, velvet, ol chamois skin from which the grease has been removed.

(b) For smaller weights the lifters may be of the sanie design, where practicable, or may be of a material softer than the weights, such as ivory, desi-graned wood, or plastics that are not affected hy alcohol. When the parts of the lifters or forceps that come in contact with the weights are not covered witl a soft material, they shall be smooth and polished and the edges on which worghts may be partially or wholly lifted shall be will rounded.

(c) If forceps are used solely for lifting sheetmetil wrights, steol forceps with gold-plated tips mar be used.

\subsubsection{WARl'ING OF LIITERS}

rleswes $J, M, S$, and $S-1$. Forceps shall be so construclesl that with use or with storage in a closed position they will not warp enough to interfere with their performance.

\subsection{Case}

Classes $J, M, S$, and $S-1$. One or more suitable cases shall be provided with each sot of weights. The case shall be so designed thut, as long as the lid remains elosed, the weighits canmot gret out of their poekets (3.7.1). 'Tle hinges and focks shall be arlequate to hold the lid closed with any reasonable handling. There shall be no discoloration of the weights due to the lining or the easo, such as might result from long storage in a warm or damp location.

Class $J$. The case shall be dustproof.

\subsubsection{Pockets}

Classes $J, S$, and $S-1$. A separate pocket shall be provided for lifters or forceps and for each weight, and all poekets shall be large enough so that no appreciable frictional force will be eneountered in inserting or removing weights. If the cover is not lined, the individual holes in the cover for the knobs of the weights shall be smooth or lined. Poekets for weights $1 \mathrm{~g}$ or cquivalent. and larger shall be lined with some soft material, such as velvet.

Class M. Either a lined pocket shall be provided, as speeified for elasses $J, S$, and S-1, or the position of the woight may be determined by a shallow ring or plate. If a guard riner or plate is used, the diameter of the unlined pocket or opening shall be at least 10 perecut larerer (and in all instances at least $2 \mathrm{~mm}$ larerer) thail the dianeter of the weight, and all parts of the case shill be designed so that the weights can be insirted or removed without danger of rubbing on any part of the case.

\subsubsection{Marking of Case}

Classes $J, M, S$, and $S-1$. The rlass and the unit or system of units shall be nualied conspicuously on the case. In addition, denominations shall be marked as follows:

Class J. Each pocket of thir ('ise shall be marked with the denomination of the wighlit to be liept in the poeket.

Class $M$. If the denomination is not marliel on the weight (3.5.1), it slall be markod beside? the pocket in which the weiglit is liept.

Classes $S$ and $S-1$. The denominations mav be marked beside the pockets in which the weights are kept.

\subsection{Tolerances}

The tolerance of a woight is the maximum allowable departure of the weight from its nominnl value.

\subsubsection{Basis For Adjustment}

Classes J, M, S, and S-1. Ordinarily, weights shall be adjusted according to their "apparent mass versus brass" ralues. How rever, in those cases in which the larger weights of a set are of 


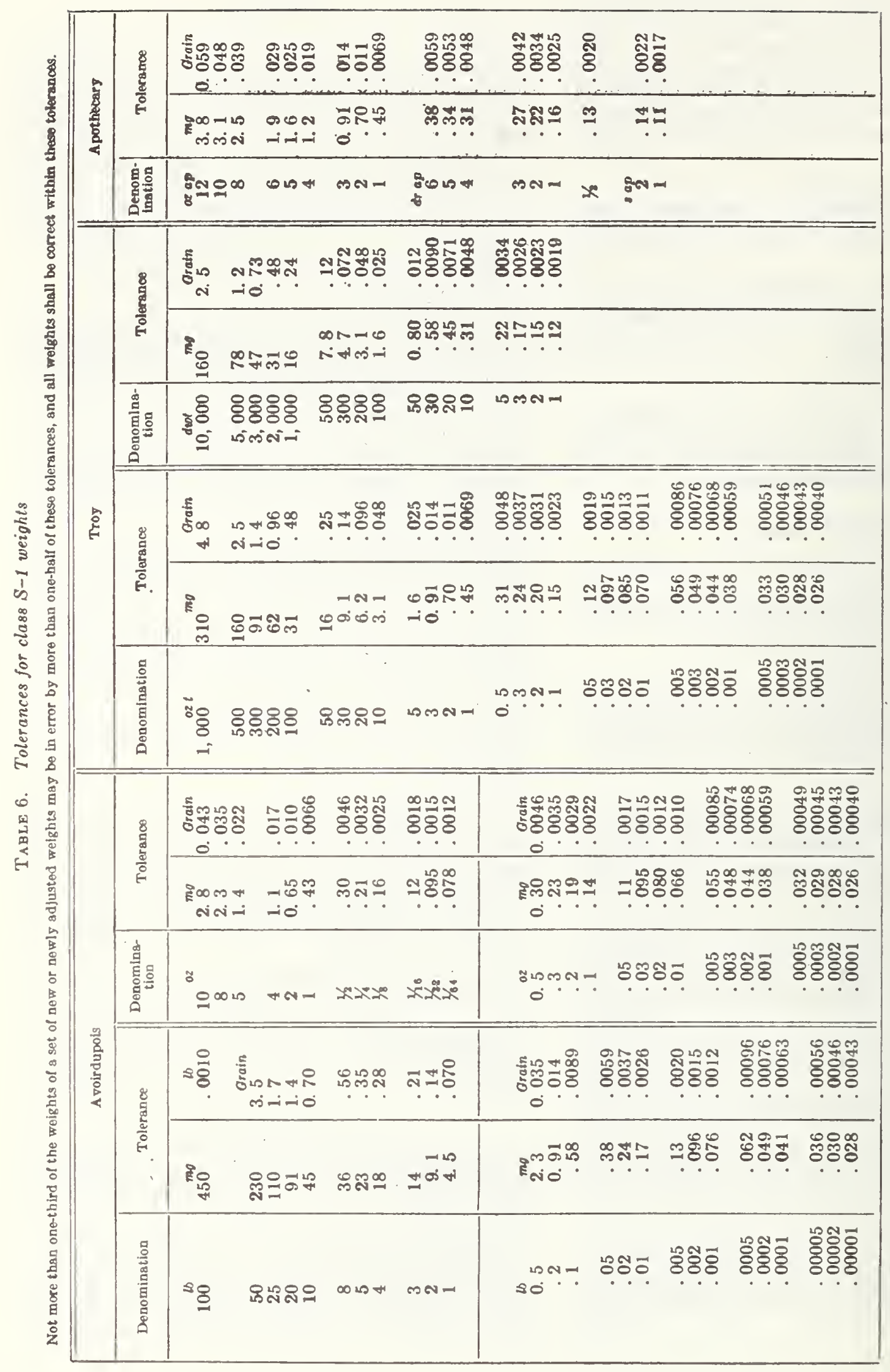




\begin{tabular}{|c|c|c|c|c|}
\hline & 产 & 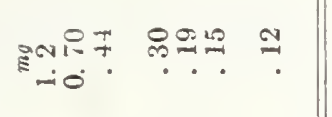 & \multirow{2}{*}{ 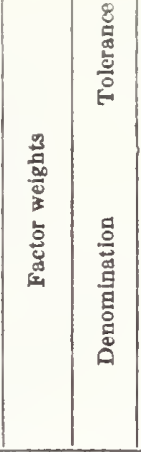 } & \multirow{2}{*}{ 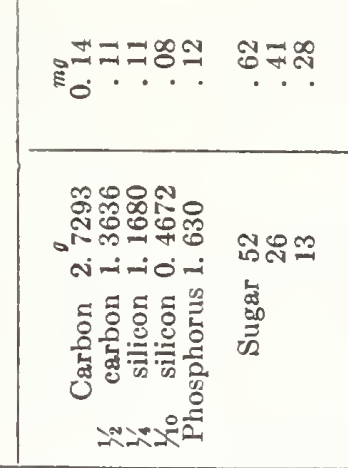 } \\
\hline 总 & 总 & $\operatorname{tin}_{\tan }$ & & \\
\hline \multirow[b]{2}{*}{ 苑 } & 尊 & \multicolumn{3}{|c|}{ 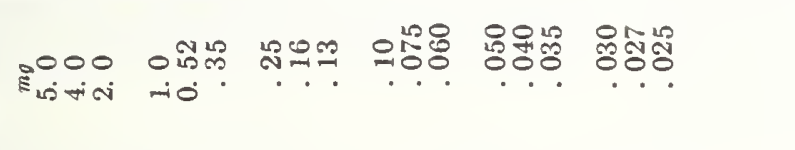 } \\
\hline & 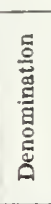 & \multicolumn{3}{|c|}{ 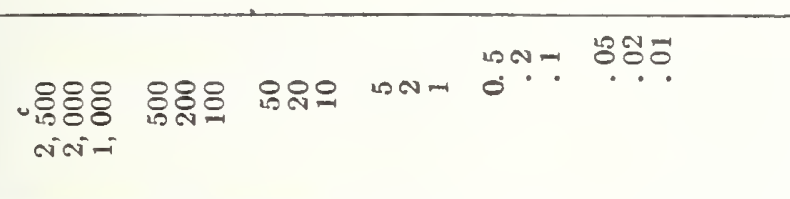 } \\
\hline \multirow{4}{*}{ 旁 } & $\frac{8}{2}$ & 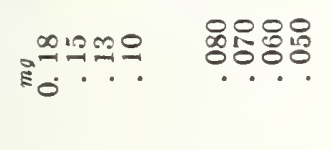 & 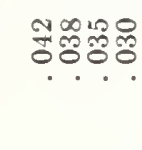 & 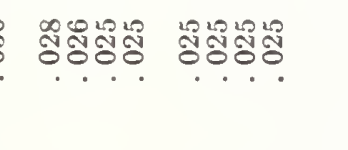 \\
\hline & 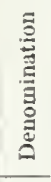 & 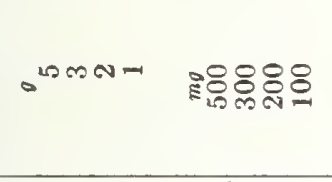 & ํำ & $\sin 20$ \\
\hline & 密 & 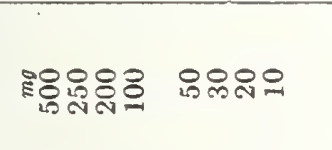 & $\begin{array}{l}0000 \\
\text { ismeini- }\end{array}$ & : \\
\hline & 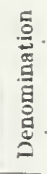 & 눈ำ & ప్దిర్లిడ్స: & 앴유은 \\
\hline \multirow{3}{*}{ 롤 } & \multirow{2}{*}{ 蒂 } & 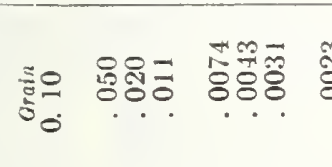 & \%ँ & 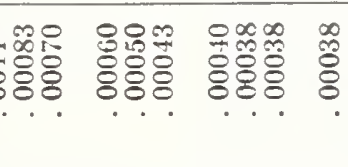 \\
\hline & & 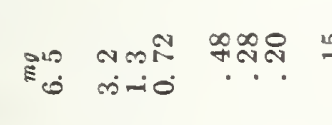 & $\because=0$. & 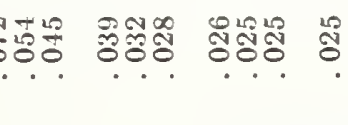 \\
\hline & 产 & 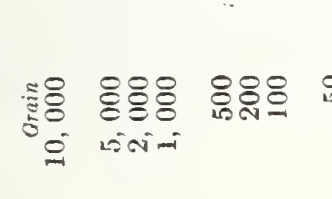 & 모은 in & 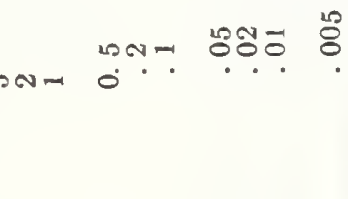 \\
\hline
\end{tabular}


some material having a density markedly different from brass, all the weights of the set may be adjusted (at the option of the purchaser) according to the apparent mass vs. platinum, tantalum, gold, or whatever is the material of the larger weights.

"Apparent mass vs. brass" values are those that the weights would be assigned on the basis of a comparison at $20^{\circ} \mathrm{C}$ in normal air against normal brass standards. "Apparent mass vs. other material" values are those that the weights would be assigned on the basis of a comparison at $20^{\circ} \mathrm{C}$ in normal air against the true mass of standards of this other material. In both cases, no corrections would be applied for the buoyant effect of the "normal air" (defined as air having a density of $1.2 \mathrm{mg} / \mathrm{cm}^{3}$ ), and values would be derived from the true mass of the standards (normal brass standards being defined as standards composed of brass having a density of $8.4 \mathrm{~g} / \mathrm{cm}^{3}$ at $0^{\circ} \mathrm{C}$ and a coefficient of cubical expansion of 0.000054 per deg Celsius (centigrade)).

\subsubsection{Acceptance Tolerances}

Classes $J, M, S$, and $S-1$. New and newly adjusted weights shall meet the tolerance requirements specified in 3.8.2.1 and 3.8.2.2.

3.8.2.1. Tolerances For Individual Weights

Class J. For weights that can be intercompared readily in a series (i. e., weights of the preferred denominations listed in table 4), the tolerance for each weight shall be $0.003 \mathrm{mg}$. For weights the denominations of which are of irregulur amounts not readily intercomparable in a series, the tolerance for each weight shall be sperified by the purchaser, but normally shall be not less than the tolerances for the class $M$ weights nearest it in value.

r'lass $M$. Individual weights shall be correct within the tolerances prescribed in table 7 in the column marked "Individual."

('lass $S$. Individual weights shall be correct within the tolcrances prescribed in table 8 in the column marked "Individual."

Clase $S-1$. Weights shall be correct within the tolerances prescribed in table 6 , and, in addition, not more than one-third of the weights of a set of new or newly adjusted weights may be iil error by more than one-half of these prescribed tolernnces.

('lasses 11, S', and $S-1$. For an individual weight of a denomination not listed in the tables, the tolerance shall be determined by proportional interpolation between tolerances given for weights of the next larger and next smaller amounts.

\subsubsection{Group Tolerances}

rlasses $M$ and $S$. The corrections of the individual weiglits shall be such that no combination of weights that is intended to be used in a weigling shall differ from the sum of the nominal values by more than the amount listed under the group tolerance. The group tolerances and the weights to which they apply are as follows:

Class M. Weights of a set that include weights less thin $10 \mathrm{~g}$ shall conform to the group tolerances prescribed in table 7 in the column marked "Group."
Class $S$. Weights of a set that inclurle weights smaller than $50 \mathrm{~g}$ shall conform to the group -tolerances prescribed in table 8 in the column marked "Group."

\subsubsection{Maintenance Tolerances}

Classes $J, M, S$, and $S-1$. Weights that have been in use shall meet the tolerance requirements specified in 3.8.2.1. and 3.8.2.2., except as follows:

Class $M$. Maintenance tolerances for weiglits from $500 \mathrm{mg}$ to $100 \mathrm{mg}$ shall be $0.0105 \mathrm{mg}$ for individual weights and $0.020 \mathrm{mg}$ for the group.

Class S. Maintenance tolerances for weiglits $100 \mathrm{mg}$ and larger shall be twice the acceptanec tolerances for these weights, as shown in table 8 both for individual weights and for decade groups.

TABLE 7. Acceptance tolerances ${ }^{1}$ for class .11 weights

\begin{tabular}{|c|c|c|}
\hline Denomination & Individual & Group \\
\hline $\begin{array}{l}\text { kg } \\
25 \\
20 \\
10\end{array}$ & $\begin{array}{c}125^{m_{0}} \\
100 \\
50\end{array}$ & $m g$ \\
\hline $\begin{array}{l}5 \\
3 \\
2 \\
1\end{array}$ & $\begin{array}{r}25 \\
15 \\
10 \\
5.0\end{array}$ & \\
\hline $\begin{array}{l}500 \\
300 \\
200 \\
100\end{array}$ & $\begin{array}{l}2.5 \\
1.5 \\
1.0 \\
0.50\end{array}$ & \\
\hline $\begin{array}{l}50 \\
30 \\
20 \\
10\end{array}$ & $\begin{array}{l}25 \\
15 \\
10 \\
050\end{array}$ & \\
\hline $\begin{array}{l}5 \\
3 \\
2 \\
1\end{array}$ & $\begin{array}{l}.034 \\
.034 \\
.034 \\
.034\end{array}$ & 0.065 \\
\hline $\begin{array}{l}m^{m} \\
500^{-} \\
300 \\
200 \\
100\end{array}$ & $\begin{array}{l}.0054 \\
.0054 \\
.0054 \\
.0054\end{array}$ & 0.0105 \\
\hline $\begin{array}{l}50 \\
30 \\
20 \\
10\end{array}$ & $\begin{array}{l}.0054 \\
.0054 \\
.0054 \\
.0054\end{array}$ & 0.0105 \\
\hline $\begin{array}{l}5 \\
3 \\
2 \\
1\end{array}$ & $\begin{array}{l}.0054 \\
.0054 \\
.0054 \\
.0054\end{array}$ & 0.0105 \\
\hline $\begin{array}{r}0.5 \\
.3 \\
.2 \\
.1\end{array}$ & $\begin{array}{l}.0054 \\
.0054 \\
.0054 \\
.0054\end{array}$ & 0.0105 \\
\hline .05 & .0054 & 0.0105 \\
\hline
\end{tabular}

1 Maintenance tolerances are the same as acceptance tolerances, except. that the malntenance tolerances for weights from $5.10 \mathrm{wig}$ to $100 \mathrm{mg}$ are 0.0105 $\mathrm{mg}$ for tndividual weights and $0.020 \mathrm{mg}$ for the group. 
Table 8. Acceptance tolerances "for class $S$ weights

\begin{tabular}{|c|c|c|}
\hline Denomlaation & Indlvldusel & Group \\
\hline $\begin{array}{l}25^{k 0} \\
20 \\
10\end{array}$ & $\begin{array}{l}\text { mo } \\
62 \\
50 \\
25\end{array}$ & $m$ \\
\hline $\begin{array}{l}5 \\
3 \\
2 \\
1\end{array}$ & $\begin{array}{r}12 \\
7.5 \\
5.0 \\
2.5\end{array}$ & \\
\hline $\begin{array}{l}500 \\
300 \\
200 \\
100\end{array}$ & $\begin{array}{r}1.2 \\
0.75 \\
.50 \\
.25\end{array}$ & \\
\hline 60 & .12 & \\
\hline $\begin{array}{l}30 \\
20 \\
10\end{array}$ & $\begin{array}{l}074 \\
.074 \\
.074\end{array}$ & 0. 154 \\
\hline $\begin{array}{l}5 \\
3 \\
2 \\
1\end{array}$ & $\begin{array}{r}.054 \\
.054 \\
.054 \\
.054\end{array}$ & 0. 105 \\
\hline $\begin{array}{l}m \rho \\
500 \\
300 \\
200 \\
100\end{array}$ & $\begin{array}{r}.025 \\
.025 \\
.025 \\
.025\end{array}$ & 0.055 \\
\hline $\begin{array}{l}50 \\
30 \\
20 \\
10\end{array}$ & $\begin{array}{l}.014 \\
.014 \\
.014 \\
.014\end{array}$ & 0.034 \\
\hline $\begin{array}{l}5 \\
3 \\
2 \\
1\end{array}$ & $\begin{array}{r}.014 \\
.014 \\
.014 \\
.014\end{array}$ & 0.034 \\
\hline $\begin{array}{r}0.5 \\
.3 \\
.2 \\
.1\end{array}$ & $\begin{array}{r}.014 \\
.014 \\
.014 \\
.014\end{array}$ & 0. 034 \\
\hline .05 & .014 & $0: 034$ \\
\hline
\end{tabular}

1 Maintenance tolerances for weights below $100 \mathrm{mg}$ are the same as the acrutince tolerances. For weights $100 \mathrm{mg}$ and above the maintenance tolerances are twice the acceptance tolerances.

\subsection{Constancy Under Variations in Humidity}

Classes $S$ and $S-1$. When the relative humidity of the surrominding atmosphere is kept at 30 percent for 3 days, raised to 70 percent and kept there for 4 days, and then brought back to 30 pereent and kept there for 2 days, neither the meran variation nor the net gain shall be more than the amounts specified or calculated in accordance with table 9 .
TABLE 9. Tolerances on variability and nel yain caused b? variations in atmospheric humidity from so percent to ro percent for weights of classes $S$ ared s'-1

\begin{tabular}{|c|c|c|}
\hline \multirow{2}{*}{$\begin{array}{l}\text { Denomina. } \\
\text { tlon }\end{array}$} & \multicolumn{2}{|c|}{$\begin{array}{l}\text { Muximum ullowable virmation wnd } \\
\text { net gain for- }\end{array}$} \\
\hline & Class $\mathrm{B}$ & Cluss 8-1 \\
\hline \begin{tabular}{r}
\multicolumn{0}{c}{} \\
$\Sigma 221$ \\
$\Sigma 200$ \\
$\Sigma 121$ \\
$\Sigma 100$ \\
$\Sigma 50$
\end{tabular} & $\begin{array}{l}m g \\
0.22 \\
.20 \\
.15 \\
.13 \\
.085\end{array}$ & $\begin{array}{r}m g \\
0.65 \\
.60 \\
.44 \\
.38 \\
.25\end{array}$ \\
\hline $\begin{array}{r}100 \\
50 \\
30 \\
20 \\
10\end{array}$ & $\begin{array}{l}.070 \\
.050 \\
.030 \\
.025 \\
.016\end{array}$ & $\begin{array}{l}21 \\
14 \\
.090 \\
.075 \\
.048\end{array}$ \\
\hline $\begin{array}{l}5 \\
3 \\
2 \\
1\end{array}$ & $\begin{array}{l}011 \\
009 \\
007 \\
005\end{array}$ & $\begin{array}{r}.032 \\
.028 \\
.020 \\
.015\end{array}$ \\
\hline
\end{tabular}

The "mean variation" is defined as the arrage of the quantities B-A and C-D, and the "net main" is defined as the quantity D-A, where $A, B, C$, and $D$ are the measured masses (corrected tor the bunvant effect of the air) of the weights under the following conditions: (A) After the first 3 dave it 30 bereent relative humidity, (B) after 1 das at 70 pereat, (C) after 4 days at 70 percent, and (D) after again being at 30 percent for 2 days.

For individual weights of denominations listed in table 9 , the allowable variation and net gain shall be as listed in the table. For individual weights of denominations not listed in the table, the allowable variations and ret gain shall be dotermined by proportional interpolation hetween values given for weights of the nest harger and next smaller amounts.

For all ordinary sets and for groups the sum of which does not exceed $250 \mathrm{~g}$ or equivilent, the allowable variation and net gain shall be applied to the sum of the weights. Larerer eroups shall be divided in any apropriate manne into groups of $250 \mathrm{~g}$ or smaller. For sets or groups of wedirits listed in table 9 , the allowable valiation and not gain shall be as listed. For sets or groups of weights not listed in the table, the allowable variation and net gain shall be equal to the sum of the amounts allowable on weirhts of the denominations actually in the sroup.

\subsection{Packaging}

This section applies to new or newly aljusted weights.

\subsubsection{Separate Package}

Classes $J, M, S$, and $S-1$. Each set of wrights 
and each individual weight not part of a set shall be packaged separately.

\subsubsection{Seal}

Classes $J, M, S$, and $S-1$. The package shall be sealed by the manufacturer or adjuster so that the weights cannot be removed from the package without destroying the seal. The weights shall be packed in accordance with 6.4 before sealing.

\subsubsection{Marking}

Classes $J, M, S$, and $S-1$. The sealed package shall be marked with the class of weight, the maximum and minimum denominations contained therein, the unit or system of units, the name of the manufacturer, the manufacturer's type num- ber, a caution against breaking the seal, and any other appropriate information.

\subsubsection{Manufacturer's Information Sheet}

Classes $J, M, S$, and $S-1$. A manufacturer's information sheet shall be packaged with new weights. It shall list the density to two or three significant figures and also the composition of the alloy, commercial grade, or accepted trade name of the material of which the weights are composed. (See 3.1 for specifications as to density and composition.) The nature of the surface protection (3.3.3) and the construction (one-piece, screw-knobs, screw-knob pinned, driven knob, etc.) shall also be described on the information sheet.

\section{Requirements for Laboratory Weights-Classes P, Q, and T}

Class $P$ (formerly class S-2). These weights are designed for routine analytical work in the scientific or technical laboratory.

Class Q. These weights are designed for use with precision pressure gages and for the technical work of commercial and student laboratories. Weights of this class are suitable for the laboratory dispensing of chemicals and pharmaceuticals, rough determination of mass in the elementary physics laboratory, etc.

Class $T$. These weights are designed for rough weighing operations in the physical and chemical laboratories, such as with force-measuring apparatus.

\subsection{Material}

\subsubsection{HARDNESS}

Classes $P, Q$, and $T$. The Knoop hardness number shall be as follows: (a) 125 or greater at a test load of $200 \mathrm{~g}$ for weights above $5 \mathrm{~g}$ or $1 / 4 \mathrm{oz}$ or equivalent (brass and harder materials); (b) 55 or greater at a test load of $100 \mathrm{~g}$ for weights of $5 \mathrm{~g}$ or equivalent and below (aluminum and harder materials).

\subsubsection{Option}

Classes $P, Q$, and $T$. If the weights are to receive rough use, the hardness requirement may be changed at the option of the purchaser to read: The Knoop hardness number shall be 225 or greater at a test load of $500 \mathrm{~g}$ for all weights (cast iron and stainless or dense steel).

\subsubsection{Corrosion Resistance}

Classes $P, Q$, and $T$. Weights shall be constructed of material that is resistant to oxidation or corrosion. Lead shall not be used. Cast iron and other metals with similar rates of oxidation may be used for weiglits of class $T$ but sliall not be used for weights of the other classes. Iron and steel shall not be used for weights of $5 \mathrm{~g}$ or $1 / 4 \mathrm{oz}$ or equivalent and below, except that stainless steel may be used for weights of all denominations.

\subsubsection{Adjusting Material}

Classes $P, Q$, and $T$. Brass, copper, aluminum, tin, or material equally resistant to oxidation and corrosion shall be used if adjusting material is required.

Classes $P$ arid $Q$. Lead shall not be used.

\subsubsection{Contamination}

Classes $P, Q$, and $T$. All surfaces, exterior and interior (including the adjusting cavity and threads of the knob) shall be free of deposits, residues, and other contaminating substances, such as cutting oil and residues from electroplating and cleaning solutions.

\subsubsection{Magnetic Properties}

Class $P$. Weights shall be constructed of nonmagnetic material, with the following exceptions or provisions:

(a) Nickel may be used for surface protection.

(b) Nonmagnetic stainless steel alloys may be used, provided the nickel content is at least 50 percent by weight of the chromium content.

(c) Dense steel, rolled or otherwise worked, may be used for weights of $10 \mathrm{~kg}$ or $20 \mathrm{lb}$ or equivalent and above.

Class Q. Class $\mathrm{P}$ specifications apply except that dense steel, rolled or otherwise worked, may be used for weights above $5 \mathrm{~g}$ or $1 / 4 \mathrm{oz}$ or equivalent. 
Class T. Class $Q$ specifications apply except that cast iron may be used for weights of $100 \mathrm{~g}$ or $4 \mathrm{oz}$ or equivalent and above.

\subsubsection{Density}

Classes $P, Q$, and $T$. Weights shall be constructed of materials having densities within the ranges shown in table 10 .

TABLE 10. Density for laboralory weights

\begin{tabular}{|c|c|c|}
\hline Class & Welghts & Allowed density \\
\hline$P, Q$ & 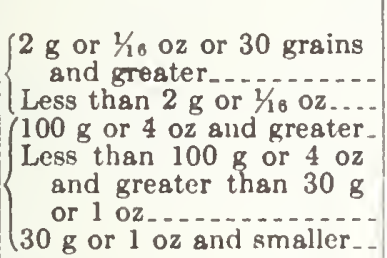 & $\begin{array}{l}\mathrm{g} / \mathrm{cm}^{\mathrm{b}} \\
7.2 \text { to } 10.0 \\
2.6 \text { and up } \\
7.0 \text { to } 10.0 \\
2.6 \text { and up } \\
1.0 \text { and up }\end{array}$ \\
\hline
\end{tabular}

\subsection{Design}

\subsubsection{Edges and Corners}

Classes $P, Q$, and $T$. A weight shall have no sharp edges or corners or other features, such as perforations or cracks, that introduce danger of excessive change with ordinary use. Shect-metal weights shall not be unnecessarily thin.

\subsubsection{Rings}

Classes $P, Q$, and $T$. A weight shall have no movable parts, except as follows:

Class T. A weight of this class may lave a ring provided that the ring is not split or removable.

\subsubsection{KNoBs}

Classes $P, Q$, and $T$. A knob shall be held in place tightly enough to prevent its working loose with ordinary handling.

\subsubsection{Shape}

C'lasses $P, Q$, and $T$. A weight shall be shaped so as not to be susceptible to undue variability, in particular:

Classes $P$ and $Q$. A weight of these classes shall not have a coin shape, unless the weight meets the hardness requirement for rough use as specified in 4.1.1.1.

\subsubsection{Adjusting Material}

Classes $P, Q$, and $T$. Adjusting material shall be securely contained and shall not project beyond the surface of the weight.

\subsection{Surface}

\subsubsection{IrREg ULARITIES}

Classes $P, Q$, and $T$. Any irregularities of the surface shall be slight and not of sharp contour. The surface shall be free from pits or pores visible to the unaided eye.

\subsubsection{Protection}

Classes $P, Q$, and $T$. A weight shall be resistant to corrosion or tarnishing by the air or by handling with the bare hands. When the base metal is of such material that protection is required, a plating such as nickel or a thin coating of transparent paint or lacquer shall be used. If transparent paint or lacquer is used, it shall be hard and not likely to chip. No lacquer or paint of any kind shall be used on sheet-metal weights or on weights composed of a material needing no surface protection. If sheet-metal weights are adjusted by fusing or plating, the adjusting material shall require no surface protection. Opaque paint may be used as follows:

Classes $P$ and $Q$. On weights above $50 \mathrm{~kg}$ or $100 \mathrm{lb}$.

Class $T$. On all weights, except as noted above.

\subsection{Denominations}

\subsubsection{INDividual Weights}

Classes $P, Q$, and $T$. Excrpt when weights are intended for a special appliration, the denominations of the weights shall be selected from table 11 .

\subsubsection{Sets of Weights}

Classes $P, Q$, and $T$. A set of weights shall include the duplicates necessary 10 permit weighing of any load within the range of the set.

\subsubsection{Optional Maximum and Minimear De- NOMINATIONS}

Classes $P, Q$, and $T$. Maximum and minimum denominations of commonly used sets of laboratory weights are given in table 12 .

\subsection{Marking of Weights}

\subsubsection{Designation of Value}

Classes $P, Q$, and $T$. The nominal mass or "value" of each weight shall be plainly marked upon it, except in the crse of riders and other wirc weights. Wire weights shall be bent in such forms as to suggest the denomination, unless they are to be used as riders or for other purposes that demand special forms. Norninal values shall be expressed in terms of one of the units listed in appendix 2 .

\subsubsection{Designation of Unit}

Classes $P, Q$, and $T$. The marking shall include the name of the unit or its accepted abbreviation in accordance with appendix 1 , except that on knob weights below $10 \mathrm{~g}$ or $1 / 2 \mathrm{oz}$ or equivalent and on sheet-metal weights below $100 \mathrm{mg}$ or 1 grain or equivalent the name of the unit may be omitted when space does not permit its inclusion in legible form. The abbreviation shall not include a period. In the case of weights of the troy or apothecary systems for which the nominal values 
TABle 11. I'referred denominations for laboralory weights

\begin{tabular}{|c|c|c|c|c|c|c|c|}
\hline \multicolumn{3}{|c|}{ Classes $F, Q$, and $T$} & \multicolumn{4}{|c|}{ Classes $P$ and $Q$} & \multirow{2}{*}{$\frac{\text { Class I }}{\text { Carst }}$} \\
\hline Metric & A voirde & & Apothecary & Tr & & Oraln & \\
\hline $\begin{array}{r}k p \\
1,000 \\
500 \\
200 \\
100 \\
50 \\
25 \\
20 \\
10 \\
5 \\
3 \\
2 \\
1 \\
\\
\\
500 \\
300 \\
200 \\
100 \\
50 \\
30 \\
20 \\
10 \\
5 \\
3 \\
2 \\
1 \\
\\
m 0 \\
500 \\
300 \\
200 \\
100 \\
50 \\
30 \\
20 \\
10 \\
5 \\
3 \\
2 \\
1 \\
0.5 \\
.3 \\
.2 \\
.1 \\
.05\end{array}$ & $\begin{array}{c}2 b \\
2,500 \\
2,000 \\
1,000 \\
500 \\
200 \\
100 \\
50 \\
25 \\
20 \\
10 \\
8 \\
5 \\
4 \\
3 \\
2 \\
1 \\
0.5 \\
.3 \\
.2 \\
.1 \\
.05 \\
.03 \\
.02 \\
.01 \\
.005 \\
.003 \\
.002 \\
.001 \\
.0005 \\
.0003 \\
.0002 \\
.0001 \\
.00005 \\
.00003 \\
.00002 \\
.00001\end{array}$ & $\begin{array}{l}10^{02} \\
8 \\
5 \\
4 \\
3 \\
2 \\
1 \\
1 / 2 \\
1 / 4 \\
1 / 8 \\
1 / 16 \\
132 \\
1 / 64 \\
0.5 \\
.3 \\
.2 \\
.1 \\
.05 \\
.03 \\
.02 \\
.01 \\
.005 \\
.003 \\
.002 \\
.001 \\
.0005 \\
.0003 \\
.0002 \\
.0001 \\
\end{array}$ & $\begin{array}{c}02 a p \\
12 \\
10 \\
8 \\
6 \\
5 \\
4 \\
3 \\
2 \\
1 \\
\\
d r a p \\
6 \\
5 \\
4 \\
3 \\
2 \\
1 \\
1 / 2 \\
\\
\text { s ap } \\
2 \\
1\end{array}$ & $\begin{array}{c}1,000^{0}{ }^{t} \\
500 \\
300 \\
200 \\
100 \\
50 \\
30 \\
20 \\
10 \\
5 \\
3 \\
2 \\
1 \\
0.5 \\
.3 \\
.2 \\
.1 \\
.05 \\
.03 \\
.02 \\
.01 \\
.005 \\
.003 \\
.002 \\
.001 \\
.0005 \\
.0003 \\
.0002 \\
.0001\end{array}$ & $\begin{array}{r}d w t \\
10,000 \\
5,000 \\
3,000 \\
2,000 \\
1,000 \\
500 \\
300 \\
200 \\
100 \\
50 \\
30 \\
20 \\
10 \\
5 \\
3 \\
2 \\
1\end{array}$ & $\begin{array}{r}\text { Grain } \\
10,000 \\
5,000 \\
3,000 \\
2,000 \\
1,000 \\
500 \\
300 \\
200 \\
100 \\
50 \\
30 \\
20 \\
10 \\
5 \\
3 \\
2 \\
1 \\
0.5 \\
.3 \\
.2 \\
.1 \\
.05 \\
.03 \\
.02 \\
.01 \\
.005\end{array}$ & $\begin{array}{c}c \\
2,500 \\
2,000 \\
1,000 \\
500 \\
300 \\
200 \\
100 \\
50 \\
30 \\
20 \\
10 \\
5 \\
3 \\
2 \\
1 \\
0.5 \\
.3 \\
.2 \\
.1 \\
.05 \\
.03 \\
.02 \\
.01 \\
\end{array}$ \\
\hline
\end{tabular}

are expressed in pounds, ounces, drams, or scruples, the identification letter " $t$ " or "ap" shall be used in addition to the name or abbreviation of the unit.

\subsubsection{Unnecessary Markings}

Classes $P, Q$, and $T$. Markings other than those required or allowed in 4.5.1 and 4.5.2 shall not be used, except as follows: (a) On weights of $25 \mathrm{~kg}$ or $50 \mathrm{lb}$ or equivalent and above, unnecessary markings such as the name or the trade mark of maker or dealer shall be limited to no more than the shortest name by which the firm commonly is known, and the numbers or letters composing the marking shall be no laiger than those of the denomination. (b) On weights less than $25 \mathrm{~kg}$ or $50 \mathrm{lb}$ or equivalent, unnecessary markings shall be . relatively inconspicuous as compared with the denomination.

\subsubsection{Depth of Marking}

Classes $P, Q$, and $T$. Raised or depressed letters or figures shall not be deeper than 0.04 inch (1 $\mathrm{mm})$.

\subsection{Lifters}

Class $P$. Special lifters or forceps shall be provided for weights of a set. All parts of the lifters that come in contact with the wcichts shall bo smooth, and shall have no sharp or rough edges. Forceps shall be so constructed that with use or with storage in a closed position they will not warp so as to interfere with their performance. 


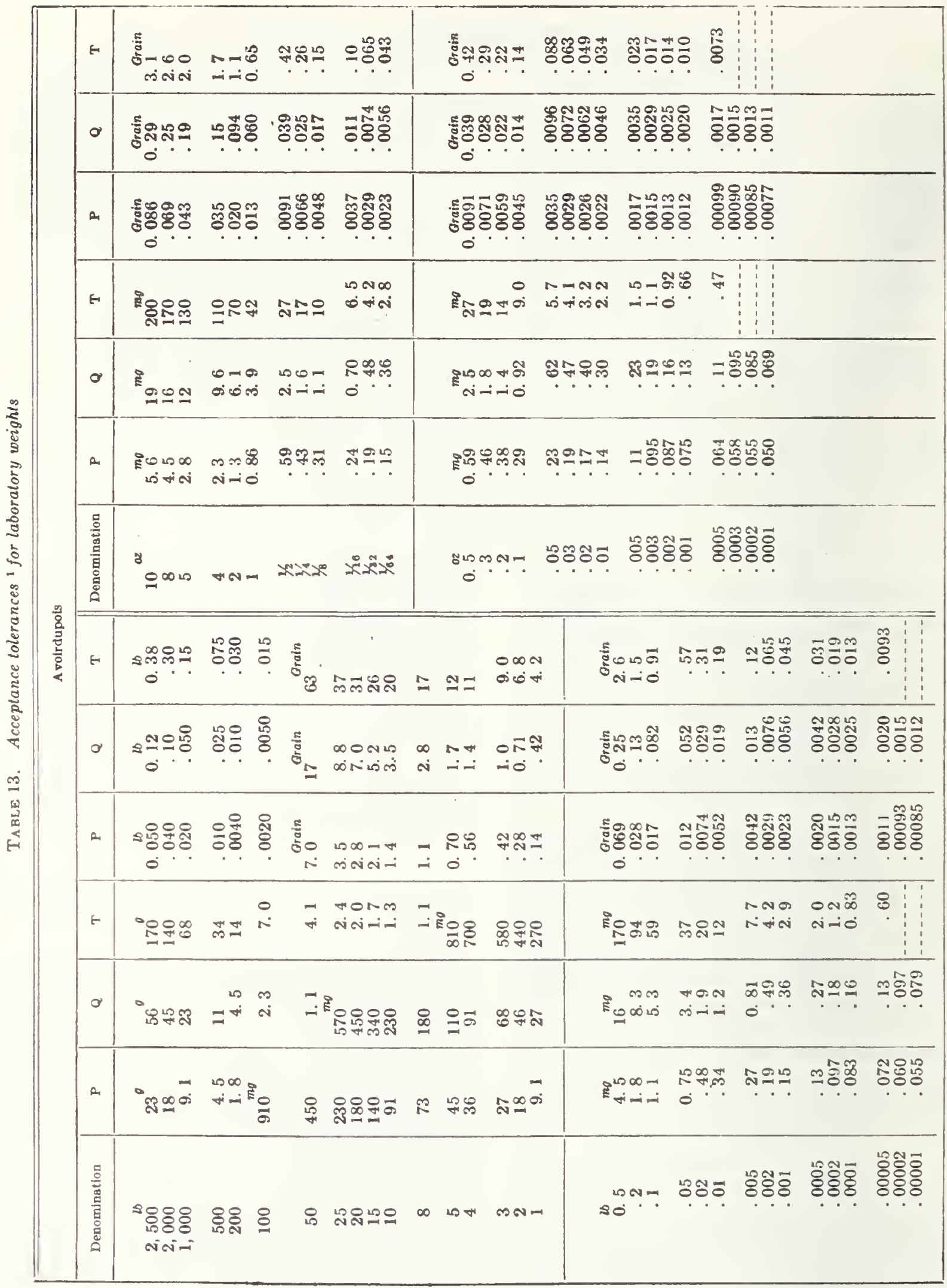




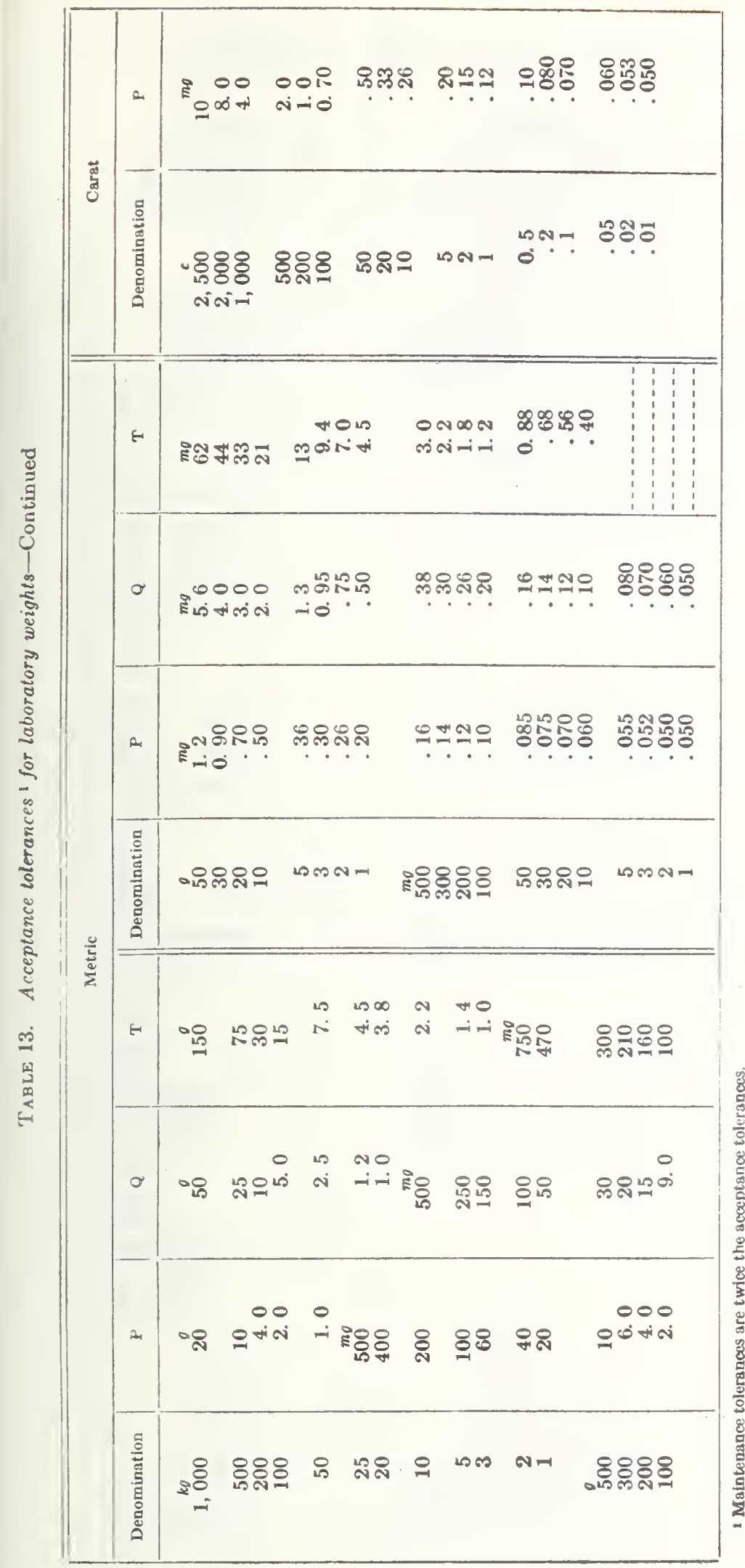




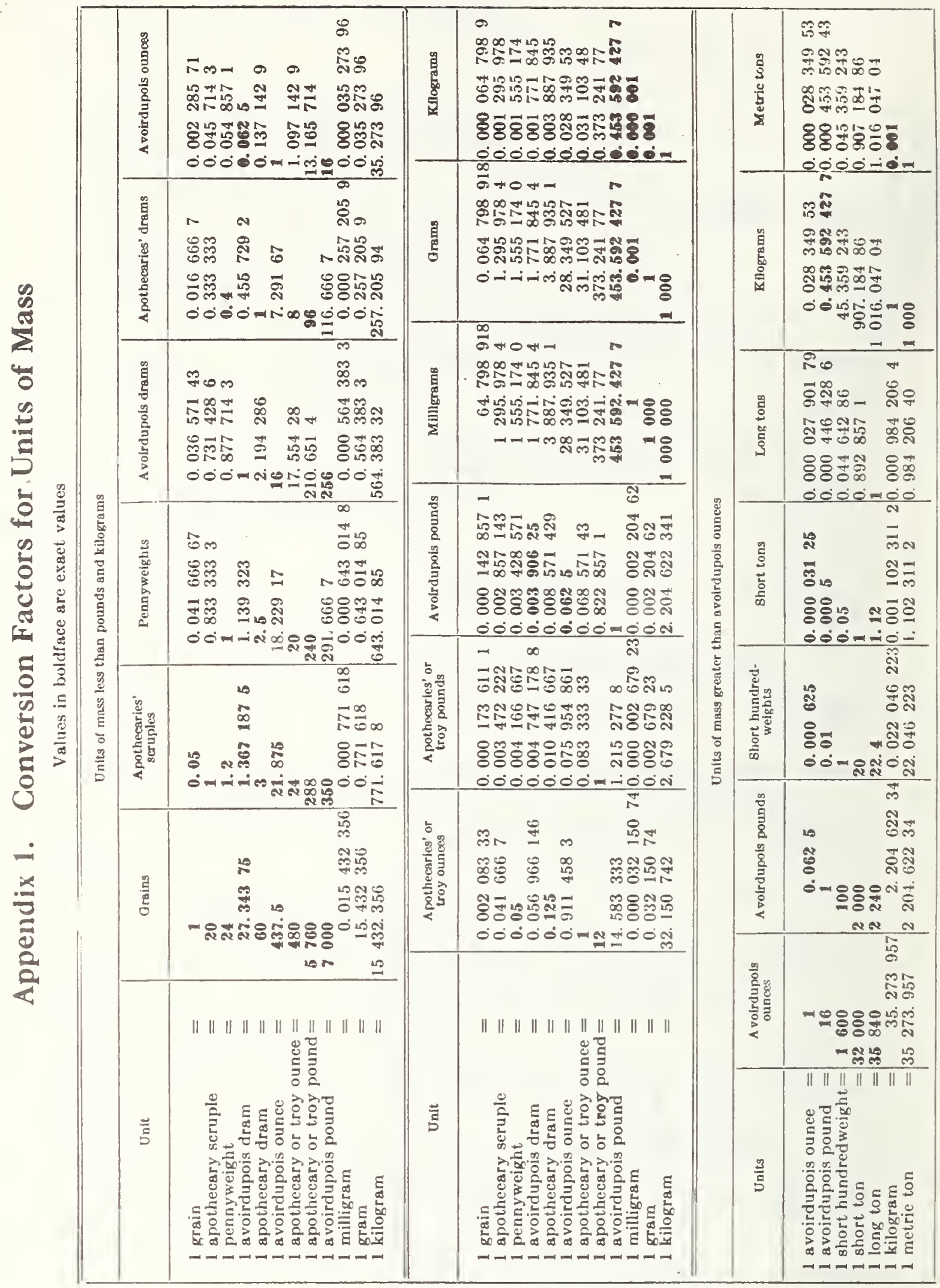




\section{Appendix 2. Units and Abbreviations for Marking Weights}

\begin{tabular}{|c|c|}
\hline Name of ualt & $\begin{array}{l}\text { Accepted } \\
\text { abbreviation }\end{array}$ \\
\hline Assay ton $(29.1667 \mathrm{~g}) \ldots$ & AT 1 \\
\hline Carat $(200 \mathrm{mg}) \ldots$ & c \\
\hline Dram, apothecaries' & $\mathrm{dr}$ ap \\
\hline Grain $\ldots \ldots \ldots \ldots \ldots$ & GN 1 \\
\hline $\begin{array}{l}\text { Gram } \\
\text { Kilogram.......... }\end{array}$ & $\mathrm{g}$ \\
\hline Milligram & $\mathbf{m g}$ \\
\hline Ounce, apothecaries' (480 grain) & oz ap \\
\hline Ounce, avoirdupois (437.5 grain) & $\mathrm{oz}$ \\
\hline Ounce, troy (480 grain) & $o z t$ \\
\hline Pennyweight & $\mathrm{dwt}$ \\
\hline Pound, avoirdupois $\ldots \ldots \ldots \ldots$ & lb \\
\hline Scruple, spothecaries' .... & 8 ap \\
\hline
\end{tabular}

I In descriptive material the abbreviation for "assay ton" should be written A. T., and "grain" should be spalled out. 


\begin{tabular}{|c|c|c|c|}
\hline $\begin{array}{l}\text { U.S. DEPT. OF COMM. } \\
\text { BIBLIOGRAPHIC DATA } \\
\text { SHEET }\end{array}$ & $\begin{array}{l}\text { 1. PUBLICATION OR REPORT NO. } \\
\text { NBSIR } 78-1476\end{array}$ & $\begin{array}{l}\text { 2. Gor't Accession } \\
\text { No. }\end{array}$ & 3. Recipient's Accession No. \\
\hline \multirow{2}{*}{\multicolumn{3}{|c|}{$\begin{array}{l}\text { 4. TITLE AND SUBTITLE } \\
\text { Precision Laboratory Standards of Mass and Laboratory Weights }\end{array}$}} & $\begin{array}{l}\text { 5. Publication Date } \\
8-20-54\end{array}$ \\
\hline & & & $\begin{array}{l}\text { 6. Performing Organization Cude } \\
732\end{array}$ \\
\hline \multicolumn{3}{|c|}{ 7. AUTHOR(S) } & 8. Performing Organ. Report No. \\
\hline \multicolumn{3}{|c|}{ 9. PERFORMING ORGANIZATION NAME AND ADDRESS } & $\begin{array}{l}\text { 10. Project/Task/Work Unit No. } \\
7320190\end{array}$ \\
\hline \multicolumn{3}{|c|}{$\begin{array}{l}\text { DEPARTMENT OF COMMERCE } \\
\text { WASHINGTON, D.C. } 20234\end{array}$} & 11. Contract/Grant No. \\
\hline \multirow{2}{*}{\multicolumn{3}{|c|}{ 12. Sponsoring Organization Name and Complete Address (Street, City, State, ZIP) }} & $\begin{array}{l}\text { 13. Type of Report \& Period } \\
\text { Covered }\end{array}$ \\
\hline & & & 14. Sponsoring Agency (.odc. \\
\hline
\end{tabular}

16. ABSTRACT (A 200-word or less factual summary of most significant information. If document includes a significant bibliography or literature survey, mention it here.)

National Bureau of Standards, Circular 547, Section 1, "Precision Laboratory Standards of Mass and Laboratory Weights," served for many years as a defining authority for various classes of weights and associated adjustment tolerances. Technological and organizational changes which occurred within a few years after the issuance gradually led to its obsolescence and consequently, it has been out of print for some time. In the interim, a new standard ASTM E617-78, "Lab Weights Precision Mass Standards," has been issued updating the same subject matter. There are still numerous requests for Circular 547 since it is widely referenced in the literature. While the document is reprinted in its entirety in NBS Handbook 77, this source is also out of print and available only at certain repository libraries. Because of technical content and historical value of Circular 547, it is being issued in the NBSIR series: of documents, to be available through NTIS. It should be noted, however, that for matters concerning calibration, one should refer to the latest copy of NBS SP250, "Calibration and Test Services of the National Bureau of Standards," available from the Office of Measurement Services.

* Sections 5, 6 and 7, which refer to obsolete procedures, have heen deleted.

17. KEY WORDS (six to twelve entries; alphabetical order; capitalize only the first letter of the first key uord unless a propet name; separated by semicolons)

Laboratory weights; mass standards; precision laboratory weights; precision mass standards; weights

18. AYAILABILITY

For Official Distribution. Do Not Release to NTIS

\begin{tabular}{|c|c|}
\hline $\begin{array}{l}\text { 19. SECURITY CL.ASS } \\
\text { (THIS REPORT) } \\
\text { UNCL ASSIFIED }\end{array}$ & $\begin{array}{l}\text { 21. NO. OF } \overline{P A C} \text {. } \\
25\end{array}$ \\
\hline $\begin{array}{l}\text { 20. SECLRITY ( LASS } \\
\text { (THISPAGE) }\end{array}$ & 22. Price \\
\hline LXCLASSIFIED & $\$ 4.00$ \\
\hline
\end{tabular}

